\title{
EXPERIMENTS IN HOUSING VESPINE COLONIES, WITH NOTES ON THE HOMING AND TOLERATION INSTINCTS OF CERTAIN SPECIES
}

\author{
By Albro Tilton Gaul
}

Brooklyn, N. Y.

During the summer of 1939 I made the following observations on some species of the Vespinæ at Lakeville, Conn. The work was not begun until early July when the wasp season had fairly advanced.

Wasp nests were captured intact, anæsthetized and transported to the laboratory for observation (1).

Hives were built to accommodate the various nests. These were wooden cases built into the open window apertures, and securely fastened and weatherstripped to keep the wasps out of the laboratory. Each hive was divided into several compartments by heavy cardboard partitions; each compartment provided a home for a single nest of hornets. The window face of the hive consisted of wire screening to admit air and light, and an adjustable aperture on the floor of the hive to control the egress of the hornets. In the laboratory each compartment was accessible through a sliding panel, with a glass observation window and a trapdoor.

Nests were placed in compartments in positions as nearly normal as possible.

When the anæsthetized colony was first placed in the hive, the aperture had to be closed to prevent the escape of the wasps. Unless this precaution were taken, the whole adult population of the nest would desert as soon as they were able to move. In one such case, the population was discovered rebuilding a nest within a few feet of the old nest site, although this was well over a mile from the laboratory. This desire to desert the nest only lasted a few hours; a colony collected in the early evening could be permitted to gather food and paper pulp next morning. 
About eight hours of confinement sufficed to persuade the adults to remain with the nest and continue their normal activities.

Once established in the new environment, a colony would not voluntarily desert despite further treatment with anæsthetic. One colony of Dolichovespula arenaria Fab. was periodically treated with ether that I might remove a portion of the nest wall for observation purposes. These did not leave the nest although they were free to do so.

As a result of enlarging the nest, one colony of Dolichovespula maculata Linn. expanded the brood comb until it came into contact with the observation window in the hive. The paper nest wall was removed by the wasps and the glass served as the wall. A similar observation was figured by A. H. Clark (2). This is evidently a normal method of building the nest into contact with any surface, as nests collected from rafters and walls of buildings exhibit the same structure.

Customarily new comb is built below the existing tiers of comb. In the circumscribed space of the compartments this could not be done, so the hornets increased the area of each comb by adding cells to the periphery.

Because of the limited vertical expansion in the compartments, some of the Dolichovespula colonies were forced to use the floor of the hive as the nest floor, without any paper. Lacking any excavating instinct, the wasps made no effort to remove the floor of the hive.

The nests gradually assumed a hemispherical shape. In these nests, the entrance was eventually made opposite the escape aperture of the hive and on the floor of the hive.

Old wasp comb and paper was supplied to assist certain colonies in gathering paper material. None would accept this paper.

Species of Vespula will also respond to hive conditions without the accustomed dampness of the earth. Few notes were made on this genus as observations were made too late in the season.

Wasps returning from the fields invariably return directly to the home window. In many cases, however, they would fail to select the proper hive compartment. Even when there were two or more species in a hive, they would re- 
peatedly enter the wrong compartment. This was so common throughout the season that a number of the wasps must have made the same error many times. I can only offer the explanation that the nests are never in such close proximity in nature, and that a return to within a few inches would normally bring a wasp to her nest. But in the hive, all compartments look alike, a nest odor (if any) is confused with the odor from adjacent nests, and a few inches error would send a wasp into the wrong compartment. Eventually, of course, the wasps would seek out their home nest.

The continued intrusion of wasps into the wrong compartments afforded excellent opportunities to observe the natural tolerance and animosity of the various species toward the intruders. The results are very similar to tolerance observations on Polistes (3).

In one hive were two maculata nests and a weakened arenaria nest. In this hive a returning maculata worker would be set upon if she ventured into the arenaria compartment; similarly an arenaria intruder would be pursued in the maculata compartments. Members of one maculata colony were permitted to enter the compartment and to walk upon the nest of the other colony; they did not enter the nest of the other colony. As a result of removing workers from the arenaria colony, the remaining population could no longer protect itself and the intruding maculata workers soon learned to steal the arenaria larvae as food for their own brood.

Two adjacent arenaria colonies in another hive permitted the same freedom of trespass on their nests as was described above for the two maculata colonies.

In flight outside the hives all the species were on good terms. They caused no trouble by virtue of their proximity.

To discover the outcome of a prolonged intrusion of one species in the compartment of another, I closed the escape aperture of an arenaria hive and placed a large maculata worker within the arenaria nest. Immediately the arenaria workers formed a circle about the intruder, always facing her and reminding me of the entourage of worker bees about their queen. As soon as the maculata moved toward the 
screening in an attempt to escape, an arenaria worker jumped upon her back and attempted to bite off the wings, all the while flexing her abdomen in an attempt to sting the intruder. After this, several "defenders" would dart forward and nip at the legs, antennae and wings and return to the circle. This darting and biting continued until the first worker succeeded in injecting her sting, which concluded hostilities. Even after death, the intruder was worried and chewed by occasional wasps. The workers removed the dead maculata from the hive five days after the battle.

The maculata made no effort to defend itself. Aside from moving to escape, it submitted to its fate. Subsequent similar experiments with intruding arenaria workers on maculata nests resulted in the same results for the intruder.

It thus seems that members of one species of Dolichovespula will tolerate guests of the same species, while they are actively hostile to the intruders of another species. They are not loath to prey upon the larvae of another species and will enter the other nest to do so if permitted.

\section{Literature Cited}

1. Gaul, A. T. A Method of Collecting Nests of Some Social Hymenoptera-Bull. Brooklyn Entom. Soc. Vol. 34, 1939, pp. 197-8.

2. Clark, A. H. Potent Personalities, Wasps and Hornets-Nat. Geog. Mag. July 1937 pp. 70-1.

3. Rau, Phil The Instinct of Animosity and Tolerance in Queen Polistes Wasps-Jour. Comp. Psychology, Vol. 27, 1939, pp. 259-69. 

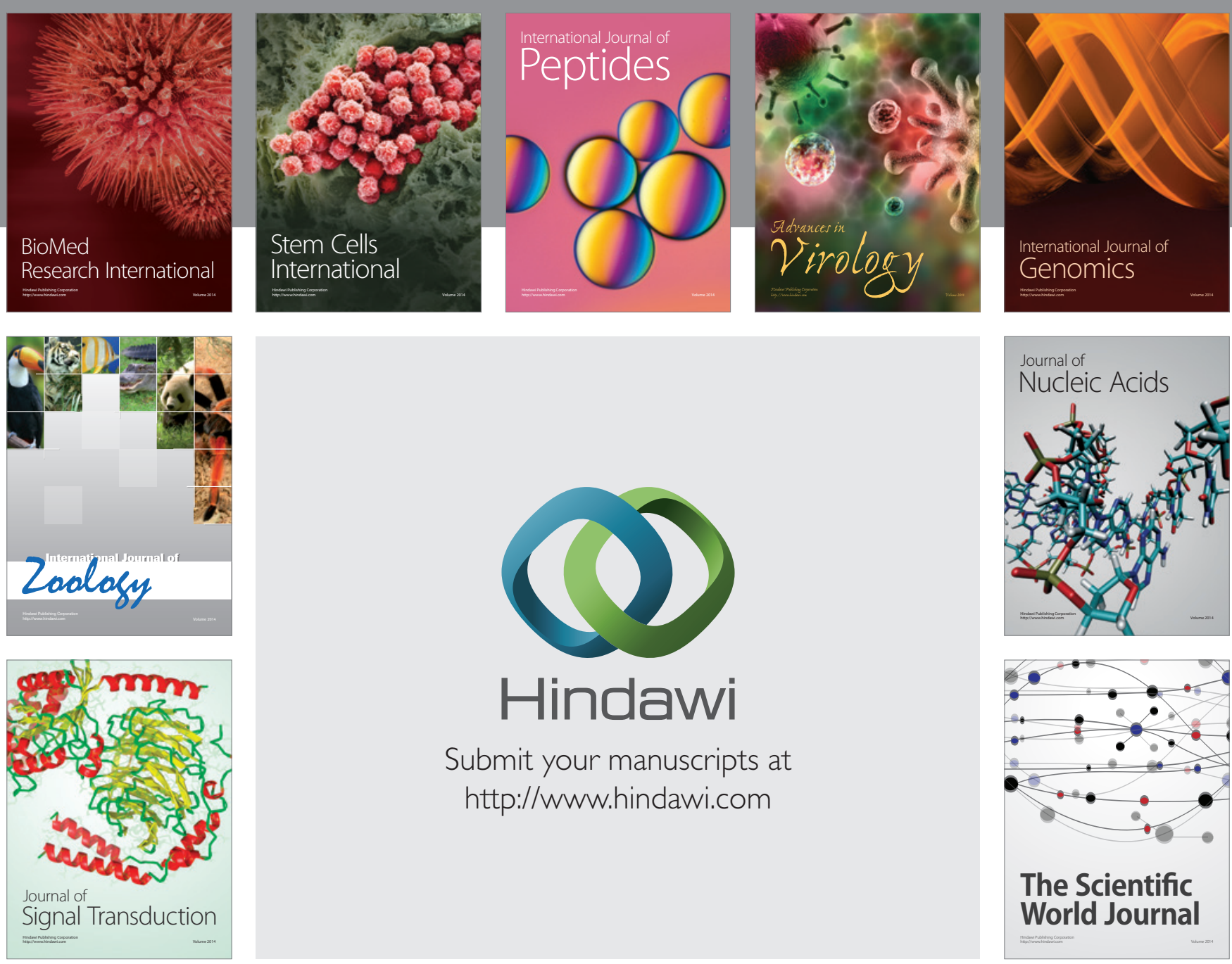

Submit your manuscripts at

http://www.hindawi.com
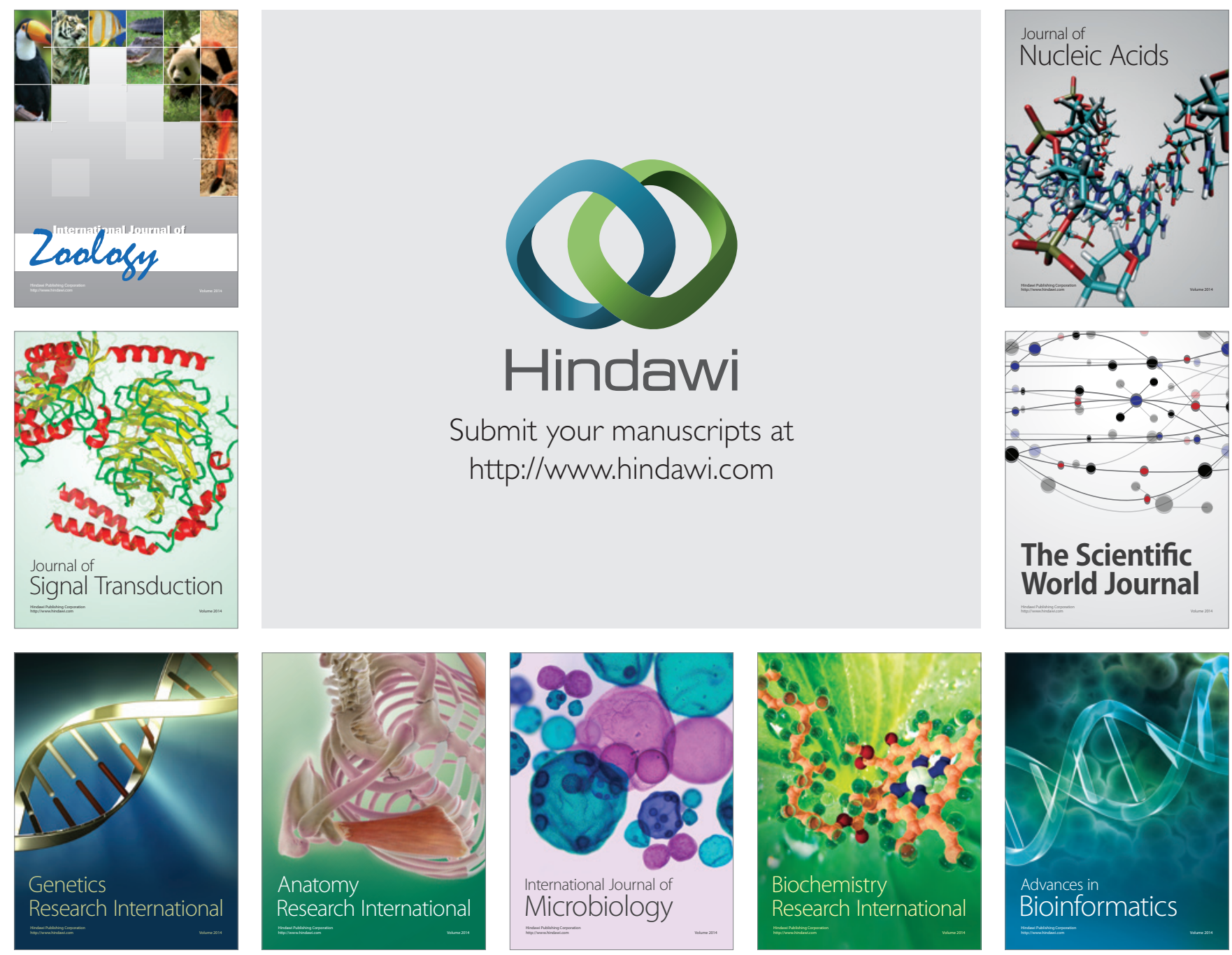

The Scientific World Journal
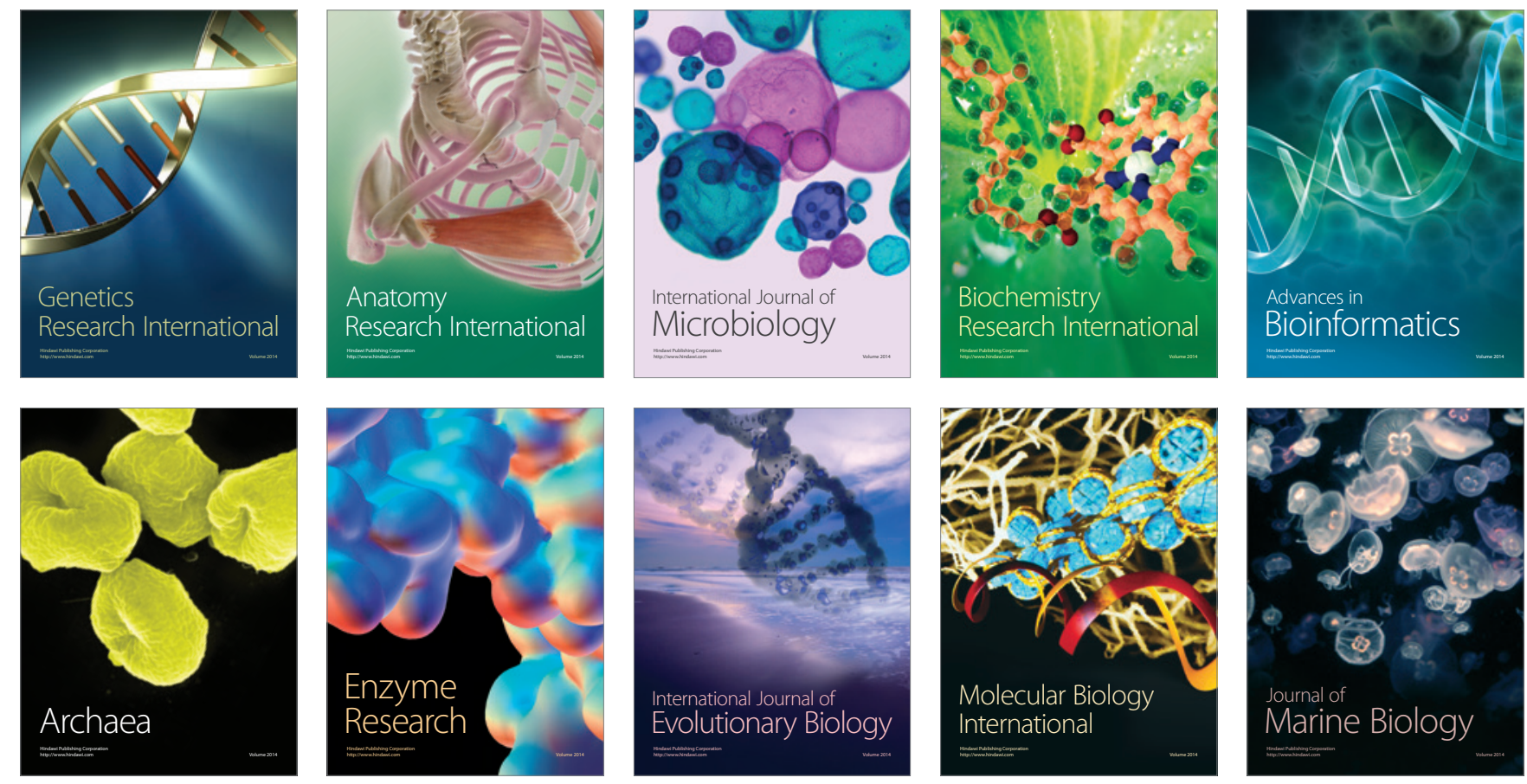